\title{
Frequencies of Abnormal Haemoglobin Electrophoretic Patterns in Hemolytic Anemia cases in District Swat.
}

\author{
Amin Ullah', Amreek Lal ${ }^{1}$, Siyab Ahmad², Akhtar Nawab¹, Salman Khan ${ }^{1}$, Ziaullh$^{1}$
}

\begin{abstract}
Background: Thalassemia is a genetic disorder due to deletion or mutation in the gene for alpha or beta chain of hemoglobin. Thalassemia, sickle cell disease, $\mathrm{HbD}, \mathrm{HbE}, \mathrm{HbC}$ and other such disorders are genetic defects associated with hemolytic anemia's and other complications. The prevalence of these are significantly growing in Pakistan especially in the northern areas of Pakistan. Its prompt detection is of paramount importance, both for the prevention of thalassemia major and clinically severe other hemoglobinopathies as well as for the epidemiological purposes.

Objective: To assess the frequencies of abnormal hemoglobin variants in the suspected cases of hemolytic anemia's, in the population of district swat.

Material and Methods: A total of 1832 suspected cases of hemolytic anemias admitted in SGTH/SMC were assessed after taking clinical and familial history. Whole blood samples were collected in EDTA tube; complete blood counts with peripheral smears were prepared. All samples were processed with fully automatic micro capillary hemoglobin electrophoretic movability (SEBEA micro capillary electrophoresis).
\end{abstract}

Results: A normal $\mathrm{Hb}$ pattern was observed in 1224 (66.81\%) cases and abnormalities were detected in 608 (33.18\%) cases. $\beta$ (beta) thalassemia trait was the commonest abnormality found in 477 (26.03\%) patients followed by $\beta$ thalassemia major $53(2.89$ $\%), \beta$ thalassemia intermedia $24(1.31 \%)$, raised $\mathrm{HbF}$ for age review after one year $17(0.92 \%)$, Sickle cell trait $9(0.49 \%)$, Sickle cell disease 8 (0.43 \%), sickle/beta-thalassemia $6(0.32 \%)$ HbD Trait $5(0.27 \%), \mathrm{HbE}(0.21 \%)$ and HbC $(0.10 \%)$ were common hemoglobinopathies.

Conclusion: Amongst hemoglobinopathies, $\beta$ - (beta) thalassemia and sick cell trait/disease is the most common of the hemoglobinopathies in the study area.

Keywords: Hemoglobinopathy, Microcapillary Hb electrophoresis, Prevalence, Thalassemia

This article may be cited as: Aminullah, Lal A, Ahmad S, Nawab A, Khan S, Ziaullah. Frequencies of Abnormal Haemoglobin Electrophoretic Patterns in Hemolytic Anemia cases in District Swat. J Saidu Med Coll Swat 2020;10(2):160-163

\section{INTRODUCTION}

Hemoglobinopathies are the most common genetically inherited disorders. The figures of World Health Organization (WHO) estimate that approximately $5 \%$ of world's population are being carriers for the genetic hemoglobin $(\mathrm{Hb})$ disorders. Every year, there are over 42 million carriers and more than 12,000 infants born with a major and clinically significant hemoglobinopathy. Relatively higher frequency of consanguineous marriages in many of the high frequency countries, has equally contributed for the increased burden of hemoglobinopathies. ${ }^{1}$

Thalassemia disorder is due to deletion or mutation in the gene for alpha or beta chain of hemoglobin. Thalassemia intermedia and thalassemia minor are heterozygous conditions and are often referred to as beta thalassemia carrier or trait. ${ }^{2}$ Beta thalassemia is widespread in Pakistan, India, the Middle East, Central Asia, and

1. Department of Medical SGTH, Swat

2. Department of Pathology, SMC, Swat

Correspondence:

Dr. Aminullah

Department of Medical SGTH, Swat.

Cell: 0333-9217130
Mediterranean countries. Southeast Asia and Cyprus have the highest beta thalassemia carrier frequency reported in the literature. Milder or carrier form of thalassemia has a 5-7\% prevalence in our country, with around 100,000 individuals affected with thalassemia major. This number is increasing, with 5-9,000 new cases are seen each year.

Hemoglobin $\mathrm{S}(\mathrm{HbS})$ is an abnormal hemoglobin that results from a point mutation. Sickle cell disorders are also prevalent in Pakistan to a significant extent, approximately $2 \%{ }^{4}$

Other hemoglobinopathies like $\mathrm{HbD}, \mathrm{HbE}$ and HBS either alone or in combination with beta thalassemia also occur in our population. The heterozygous state of this condition is trait, while the homozygous state or compound is called disease. Almost 30,000 children are born every year with these hemoglobinopathies mostly occurring in overdeveloped or developing countries. The prevalence of thalassemia and hemoglobinopathy varies geographically but it has been estimated that in pakistan per 1000,1.34 have $\mathrm{Hb}$ disorder. 
Micro capillary $\mathrm{Hb}$ electrophoresis movability is one of the main approaches for the diagnosis and prevention of different hemoglobinopathies. This technique provides rapid, reproducible, and precise results. Detailed clinical history including family history and different hematologic parameters such as complete blood count (CBC), reticulocyte count, and red cell morphology is often required to help and confirm the diagnosis. ${ }^{6}$

The rationale of present study was to identify the frequencies of abnormal haemoglobin patterns (which are found in significant numbers and clusters in our area due to consanguineous marriages) in order to give further inputs towards devising a strategy for prevention and early detection of more common complications. This will also help in developing a comprehensive care policy for these patients with early referral to concerned specialties for further management, thereby reducing the morbidity and mortality.

\section{MATERIALAND METHODS}

This study was conducted at Saidu Group of Teaching Hospitals/ Saidu Medical College. The duration of this study was two years, from $1^{\text {st }}$ June 2018 to $30^{\text {th }}$ July 2020 . A total of 1832 (821 males and 1011 females) admitted in Saidu Group of Teaching Hospital presented with hemolytic anemia were recruited. Patients with decreased haemoglobin levels and peripheral smears indicative of hemolytic anemias and those patients having positive family history of inherited hemolytic anemia were included in the study. Transfusion-dependent children and adults were also included. Patients with a recent history of transfusion, i.e. within 3 months of sample collection were excluded from the study.

Blood samples were collected in EDTA tubes and analyzed with Sysmex XN 1000, an automated cell counter for Complete Blood Count (CBC). A peripheral blood smear and retic stained slide were prepared and red cell morphology was observed microscopically, to aid the diagnosis of hemoglobinopathies and other variants. Tests were carried out on the Minicap flex-piercing (SEBEA micro capillary electrophoresis system). Charged molecules, in an alkaline solution with a specific $\mathrm{pH}$ due to their electrophoretic mobility are distinguished. Appropriate controls were applied at all levels. The $\mathrm{Hb}$ A2 value $>3.5$ per cent was considered a cutoff point for beta thalassemia minor.

\section{RESULTS}

Out of total 1832 cases, presented with hemolytic anemia, with age ranged between one month to 73 years were included in the study. 1224 case were having normal hemoglobin level.

The most common haemoglobin abnormality detected was $\beta$ (beta) thalassemia trait present in $477(26.03 \%)$ patients followed by $\beta$ thalassemia major 53 (2.89\%), $\beta$ thalassemia intermedia 24 $(1.31 \%)$, raised $\mathrm{HbF}$ for age review after one year $17(0.92 \%)$ the second most prevailing abnormality was sickle cell trait $9(0.49 \%)$, Sickle cell disease $8(0.43 \%)$, sickle/beta-thalassemia 6 (0.32 \%) HbD Trait 5 (0.27 \%), HbE/betathalassemia $4(0.21 \%)$, HbD disease $3(0.16 \%)$, $\mathrm{Hb}-\mathrm{C}$ disease $2(0.10 \%)$. Table 1 shows the overall frequencies of various hemoglobinopathies.

Table 1. Distribution of hemoglobin patterns.

\begin{tabular}{|c|c|c|}
\hline Patterns of haemoglobin & Number of cases & Percentages \\
\hline Normal & 1224 & $66.81 \%$ \\
\hline$\beta$-thalassemia minor & 477 & $26.03 \%$ \\
\hline$\beta$-thalassemia major & 53 & $2.89 \%$ \\
\hline$\beta$-thalassemia intermedia & 24 & $1.31 \%$ \\
\hline Raised HbF for age review after one year & 17 & $0.92 \%$ \\
\hline Sickle cell trait & 9 & $0.49 \%$ \\
\hline Sickle cell disease & 8 & $0.43 \%$ \\
\hline sickle/beta-thalassemia & 6 & $0.32 \%$ \\
\hline HbD Trait & 5 & $0.27 \%$ \\
\hline HbE/beta-thalassemia & 4 & $0.21 \%$ \\
\hline HbD disease & 3 & $0.16 \%$ \\
\hline Hb-C disease & 2 & $0.10 \%$ \\
\hline
\end{tabular}


Table 2. Hematological parameters of common hemoglobinopathies (mean \& standard deviation)

\begin{tabular}{|c|c|c|c|c|c|c|}
\hline Hemoglobinopathy & $\begin{array}{c}\mathbf{H b} \\
\text { (g/dl) }\end{array}$ & $\begin{array}{c}\text { RBCs } \\
(\times 1012 / I)\end{array}$ & PCV (\%) & $\operatorname{MCV}(\mathrm{fl})$ & $\begin{array}{c}\mathrm{MCH} \\
(\mathrm{pg})\end{array}$ & 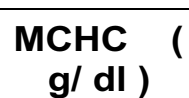 \\
\hline$\beta$-thalassemia minor & $\begin{array}{l}8.8 \pm \\
2.28\end{array}$ & $\begin{array}{r}4.5 \pm \\
1.15\end{array}$ & $\begin{array}{c}33.9 \pm \\
7.3\end{array}$ & $\begin{array}{c}68.5 \pm \\
11.6\end{array}$ & $20.1 \pm 6.9$ & $\begin{array}{c}31.0 \pm \\
34.7\end{array}$ \\
\hline$\beta$-thalassemia major & $\begin{array}{c}4.7 \pm \\
1.9\end{array}$ & $\begin{array}{c}3.61 \pm \\
0.9\end{array}$ & $19.7 \pm 10$ & $\begin{array}{l}72.7 \pm \\
8 .\end{array}$ & $22.8 \pm 9.5$ & $30.3 \pm 7.6$ \\
\hline $\begin{array}{c}\beta \text {-thalassemia } \\
\text { intermedia }\end{array}$ & $\begin{array}{c}6.1 \pm \\
1.7\end{array}$ & $\begin{array}{c}3.71 \pm \\
0.4\end{array}$ & $17.7 \pm 17$ & $\begin{array}{l}71.3 \pm \\
8 .\end{array}$ & $19.8 \pm 9.5$ & $29.3 \pm 6.6$ \\
\hline $\begin{array}{l}\text { Raised } \mathrm{HbF} \text { for age } \\
\text { review after one year }\end{array}$ & $\begin{array}{l}8.8 \pm \\
3.28 \\
\end{array}$ & $\begin{array}{l}4.0 \pm \\
2.15 \\
\end{array}$ & $\begin{array}{c}29.9 \pm \\
7.3 \\
\end{array}$ & $\begin{array}{c}59.5 \pm \\
11.6 \\
\end{array}$ & $17.1 \pm 6.9$ & $\begin{array}{c}32.0 \pm \\
34.7 \\
\end{array}$ \\
\hline Sickle cell trait & $11 \pm 3.6$ & $\begin{array}{l}4.5 \pm \\
44.5\end{array}$ & $33 \pm 22.4$ & $\begin{array}{l}66 \pm \\
32.5\end{array}$ & $18 \pm 23.4$ & $32 \pm 2.5$ \\
\hline Sickle cell disease & $\begin{array}{c}7.9 \pm \\
3.4\end{array}$ & $\begin{array}{l}3.8 \pm \\
34.6\end{array}$ & $26 \pm 23.5$ & $\begin{array}{l}81 \pm \\
34.5\end{array}$ & $24 \pm 34.5$ & $31 \pm 32.4$ \\
\hline $\begin{array}{l}\text { sickle/beta- } \\
\text { thalassemia }\end{array}$ & $\begin{array}{c}7.7 \pm \\
1.6\end{array}$ & $3.6 \pm 0.7$ & $\begin{array}{c}26.2 \pm \\
4.6\end{array}$ & $\begin{array}{c}72.8 \pm \\
8.2\end{array}$ & $23.6 \pm 3.1$ & $32.4 \pm 1.9$ \\
\hline HbD Trait & $\begin{array}{c}10.3 \pm \\
3.6\end{array}$ & $4.3 \pm 1.3$ & $\begin{array}{c}25.4 \pm \\
27.3\end{array}$ & $28.2 \pm 4$ & $19.4 \pm 7.3$ & $9 \pm 3.5$ \\
\hline $\mathrm{HbE} /$ beta-thalassemia & $\begin{array}{l}6.7 \pm \\
34.2 \\
\end{array}$ & $\begin{array}{l}3.2 \pm \\
34.4\end{array}$ & $21 \pm 34.3$ & $\begin{array}{l}64 \pm \\
33.5 \\
\end{array}$ & $17 \pm 6.5$ & $25 \pm 4.6$ \\
\hline HbD disease & $\begin{array}{l}6.7 \pm \\
2.7\end{array}$ & $2.8 \pm 1.8$ & $\begin{array}{c}17.6 \pm \\
2.1\end{array}$ & $\begin{array}{c}71.8 \pm \\
1.4\end{array}$ & $20.2 \pm 6.3$ & $28.1 \pm 3.5$ \\
\hline $\mathrm{Hb}-\mathrm{C}$ disease & $9 \pm 3.4$ & $4.6 \pm 3,5$ & $29 \pm 3.5$ & $65 \pm 5.2$ & $17 \pm 4.6$ & $13 \pm 3.5$ \\
\hline
\end{tabular}

Table 3. Haemoglobin Electrophoresis results in different hemoglobinopathies (mean and standard deviation)

\begin{tabular}{|c|c|c|c|c|c|c|c|}
\hline $\begin{array}{c}\text { Hemoglobinopathies } \\
\text { (No. of pts.) }\end{array}$ & $\mathrm{HbA} \%$ & $\mathrm{HbA} 2 \%$ & $\mathrm{HbF} \%$ & $\mathrm{HbD} \%$ & $\mathrm{HbE} \%$ & $\mathrm{HbS} \%$ & $\mathrm{HbC} \%$ \\
\hline Normal & $\begin{array}{l}97.28 \pm \\
0.47\end{array}$ & $\begin{array}{l}2.56 \pm \\
0.53\end{array}$ & $\begin{array}{l}0.52 \pm \\
0.14\end{array}$ & ------ & ------ & ------ & \\
\hline$\beta$-thalassemia minor & $\begin{array}{c}94.1 \pm \\
1.37\end{array}$ & $5.54 \pm 1.0$ & $1.4 \pm 1.22$ & ------ & ------- & ------- & \\
\hline$\beta$-thalassemia major & $\begin{array}{c}63.7 \pm \\
24.8\end{array}$ & $2.9 \pm 1.1$ & $\begin{array}{c}82.3 \pm \\
28.7\end{array}$ & ------ & ------- & ------- & \\
\hline $\begin{array}{c}\beta \text {-thalassemia } \\
\text { intermedia }\end{array}$ & $\begin{array}{l}65.7 \pm \\
24.8\end{array}$ & $2.8 \pm 1.1$ & $\begin{array}{l}73.3 \pm \\
28.7\end{array}$ & ------ & ------- & ---- & \\
\hline $\begin{array}{c}\text { Raised } \mathrm{HbF} \text { for age } \\
\text { review after one } \\
\text { year }\end{array}$ & $\begin{array}{l}91.0 \pm \\
11.7\end{array}$ & $\begin{array}{c}2.34 \pm \\
0.49\end{array}$ & $\begin{array}{c}7.12 \pm \\
11.1\end{array}$ & ----- & ------- & ------- & \\
\hline Sickle cell trait & $63 \pm 1.6$ & $1.8 \pm 0.56$ & $28 \pm 0.34$ & ----- & ------- & $\begin{array}{c}33.7 \pm \\
32.5\end{array}$ & \\
\hline Sickle cell disease & $41 \pm 23.5$ & $2 \pm 3.7$ & $28 \pm 0.56$ & ----- & $===$ & $\begin{array}{c}73 \pm \\
27\end{array}$ & \\
\hline $\begin{array}{l}\text { sickle/beta- } \\
\text { thalassemia }\end{array}$ & $45 \pm 22.8$ & $\begin{array}{l}4.17 \pm \\
0.94\end{array}$ & $27.4 \pm 0.0$ & ------ & ------- & $\begin{array}{l}64.5 \pm \\
29.5\end{array}$ & \\
\hline HbD Trait & $64.3 \pm 7.5$ & $2.9 \pm 5.9$ & ------ & $\begin{array}{l}33.3 \pm \\
7.3\end{array}$ & ------ & ----- & \\
\hline $\begin{array}{l}\mathrm{HbE} / \text { beta- } \\
\text { thalassemia }\end{array}$ & $32 \pm 34.5$ & ------- & $30 \pm 12.6$ & ------ & $\begin{array}{l}26 \pm \\
45.5\end{array}$ & & \\
\hline $\mathrm{HbD}$ disease & $\begin{array}{c}7.12 \pm \\
11.1 \\
\end{array}$ & $2.3 \pm 0.9$ & $\begin{array}{c}7.12 \pm \\
11.1 \\
\end{array}$ & $\begin{array}{c}96 \pm \\
3.2 \\
\end{array}$ & ------ & ------ & \\
\hline $\mathrm{Hb}-\mathrm{C}$ disease & $====$ & $3 \pm 45.9$ & $4 \pm 43.7$ & & & & $\begin{array}{l}93 \pm \\
3.7\end{array}$ \\
\hline
\end{tabular}




\section{DISCUSSION}

In our study the most common hemoglobin abnormality detected is that of $\beta$ thalassemia trait $(26.03 \%)$ followed by $\beta$ thalassemia major $(2.89 \%)$ and then $\beta$ thalassemia intermedia (1.31\%). $0.49 \%$ of cases carried sickle cell trait. $0.43 \%$ were sickle cell disease, $0.32 \%$ were $\mathrm{HbE} /$ Beta-thalassemia, $\mathrm{HbD}$ were $0.16 \%$ and $0.10 \%$ carried $\mathrm{HbC}$. Several studies reveal that in most parts of Pakistan, $\beta$ thalassemia trait was the commonest $\mathrm{Hb}$ disorder, Waheed et $\mathrm{al}^{7}$ study also supports our finding that thalassemia trait is the most common type of hemoglobinopathy in Pakistan (26.03\%).

The overall frequency of hemoglobinopathies in our study was $33.18 \%$. This finding is similar to the study done by Waheed et $\mathrm{al}^{7}$ in Islamabad revealing a frequency of $28.4 \%$ of different abnormal hemoglobin variants. In another research conducted by Saleem et al. ${ }^{8}$ on the pattern of distribution of hemoglobinopathies in northern areas of Pakistan, Out of the 1187 cases of refractory anemia, 305 $(25.69 \%)$ had pathological haemoglobin variants which were lower than our sample $(33.18 \%)$. An approximate 5000- 9000 children with $\beta$ thalassemia are born annually, although there is no documentary registry available in Pakistan. The projected carrier penetration is $5-7 \%$, with 9.8 million carriers in the total populaton. ${ }^{9}$

Thalassemia is one of the most common genetic disorders in the world; 4.83 per cent of the world's population has globin chain variants, including 1.67 per cent of the population that are heterozygous for $\alpha$-thalassemia and $\beta$-thalassemia. Colah $\mathrm{R}$ et al. ${ }^{10}$ reported that nearly $1.5 \%$ of the world population was carriers of $\beta$ thalassemia. Thus, the worldwide birth rate of homozygous or heterozygous compounds for symptomatic globin chain disorders, including $\alpha$-thalassemia and $\beta$-thalassemia, is no less than 2.4 per 1000 births. $^{11}$

In Pakistan, awareness of thalassemia prevention is growing, but we are far behind the needed implementation and awareness of premarital screening. Our study seeks to determine the frequency of various hemoglobinopathies in the district swat area that may be useful in the prevention and management of various hemoglobinopathies, which may play a vital role in the management blood bank hospital and in the formulation of transfusion policies. Adequate measures and screening procedures, particularly prenatal diagnosis, should be taken at the same time to reduce the risk of haemoglobin disorders in the offspring's, to reduce the mental, physical distress of the affected patients and the socioeconomic burden of the family. Screening is an inexpensive and effective way to identify carriers and can be provided in a number of settings in various societies: high school, premarital, or antenatal clinics.

\section{CONCLUSION}

Amongst hemoglobinopathies, $\beta$ (beta) thalassemia and sick cell trait/disease is the most common hemoglobinopathies in the study area.

\section{RECOMMENDTIONS}

Because of the high prevalence of $\beta$ (beta) thalassemia trait hemoglobinopathy in this region, a routine premarital screening program is needed for the identification and prevention of high-risk marriages and thus, prevention of the psychosocial trauma of bearing a transfusion dependent child for life, even though the thalassemia prevention and control act has already been passed from kpk assembly.

\section{CONFLICT OF INTEREST:}

There was no conflict of interest.

\section{REFERENCES}

1. Warghade S, Britto J, Haryan R, Dalvi T, Bendre R. Prevalence of hemoglobin variants and hemoglobinopathies using cation- chromatography in central reference laboratory of India?: A report of 65779 cases. J Lab Physicians. 2020;73-79.

2. Ansari S, Rashid N, Hanifa A, Siddiqui S, Kaleem B, $\mathrm{Naz} A$, et al. Laboratory diagnosis for thalassemia intermedia?: Are we there yet?? J of Clinical Lab Analysis. 2019;4(5):18-21.

3. Shabbir S, Nadeem M, Sattar A, Ara I, Ansari S, Farzana $T$, et al. Type and frequency of hemoglobinopathies, diagnosed in the area of Karachi, in Pakistan. J Cogent Med. 2016;3(1):22-29.

4. Harteveld $\mathrm{cl}$, ponjee $\mathrm{g}$, bakker-verweij $\mathrm{m}$, arkesteijn sgj. Hb Haaglanden: A new nonsickling $\beta 7 \mathrm{Glu}>\mathrm{Val}$ variant. Consequences for basic diagnostics, screening, and risk assessment when dealing with HbS-like variants. Int J Lab Hematol. 2012;34(5):551565.

5. Wajcman $\mathrm{H}$, Moradkhani K. Abnormal haemoglobins: detection \& characterization. Indian J Med Res. 2016;134(4):538-546.

6. Hwang S, Thevarajah M, Alias $Y$, Mei S. Current aspects in hemoglobin $\mathrm{A} 1 \mathrm{C}$ detection?: A review Clin Chim Acta. 2015;439:202-211.

7. Waheed U, Satti HS, Farooq N, Zaheer HA. Frequency of haemoglobinopathies: a single-centre, cross-sectional study from Islamabad, Pakistan. East Mediterr Health J. 2015 Dec;18(12):1257-1269.

8. Saleem M, Bilal M, Anwar J, Mazhar M. Hypothyroidism in beta thalassemia major patients at rahim yar khan. J Sheikh Zaid Med. 2016;7(3):10161019.

9. Ehsan $\mathrm{H}$, Wahab A, Anwer F, Iftikhar R, Yousaf MN. Prevalence of Transfusion Transmissible Infections in Beta-Thalassemia Major Patients in Pakistan?: A Systematic Review. J Cureus 2020;12(8):10-15.

10. Colah R, Gorakshakar A, Nadkarni A. Global burden, distribution and prevention of beta-thalassemias and hemoglobin $E$ disorders. Expert Rev Hematol. 2015;3(1):103-117.

11. Sciences $H$, Bengaluru $K$. Screening for $\beta$ thalassemia trait using discriminatory indices and electrophoresis in paediatric age group. j Rajarajeswari Medical College 2018:7(6):13-17. 